\title{
Comparision of physico-chemical, microbiological and sensory quality of Rava Burfi with Mawa Burfi
}

APARNA A. SHRIVAS, SUNEETA V. PINTO AND SUNIL M. PATEL

Received: 15.06.2017; Revised: 20.10.2017; Accepted: 03.11.2017

See end of the paper for authors' affiliations SUNEETA V. PINTO

Department of Dairy Technology, SMC College of Dairy Science, Anand Agricultural University, ANAND (GUJARAT) INDIA

Email : suneetavpinto@aau.in
ABSTRACT : In the present study, changes in compositional, physico-chemical, rheological, sensory and microbial properties (SPC, yeast and mould count and coliform count) of Rava burfi and Mawa burfi were compared.

KEY WORDS: Burfi, Rava, Khoa, Liquid glucose

- HOW TO CITE THIS PAPER : Shrivas, Aparna A., Pinto, Suneeta V. and Patel, Sunil M. (2017). Comparision of physico-chemical, microbiological and sensory quality of Rava Burfi with Mawa Burfi. Asian J. Home Sci., 12 (2) : 522-530, DOI: 10.15740/HAS/AJHS/12.2/522-530. 